\title{
ANALISIS KETERAMPILAN BERIKIR KRITIS SISWA SMA DI KECAMATAN SAKO DAN ALANG-ALANG LEBAR
}

\section{CRITICAL THINKING SKILL'S ANALYSIS OF HIGH SCHOOL STUDENTS IN DISTRICTS OF SAKO AND ALANG-ALANG LEBAR}

\author{
Heni Kurniyasari ${ }^{1)}$, Saleh Hidayat ${ }^{2)}$, Binar Azwar Anas Harfian ${ }^{3)}$ \\ 1),2),3) FKIP Universitas Muhammadiyah Palembang \\ Email : henikhan13@gmail.com \\ diterima : 20 Desember 2019; dipublikasi : 30 Maret 2019 \\ DOI: http://dx.doi.org/10.32528/bioma.v4i1.2646
}

\begin{abstract}
ABSTRAK
Penelitian ini bertujuan untuk mengetahui persentase tingkat penguasaan keterampilan berpikir kritis siswa SMA di Kecamatan Sako dan Kecamatan Alangalang Lebar. Penelitian ini dilakukan dengan metode deskriptif kuantitatif. Sampel diambil dengan teknik purposive sampling. Teknik pengumpulan data dengan nontes dan tes. Analisis data menggunakan Ms. Excel dengan menghitung persentase tingkat penguasaan. Hasil penelitian menunjukkan Kecamatan Sako terkategori rendah dengan persentase sebesar 38,99\% dan Kecamatan Alang-alang Lebar terkategori sedang dengan persentase 52,99\%. Indikator yang terkategori rendah di Kecamatan Sako adalah menganalisis $40,09 \%$, mengevaluasi $25,82 \%$, dan menjelaskan $34,97 \%$. Indikator tertinggi adalah pengaturan diri 53,27\%. Di Kecamatan Alang-alang Lebar indikator dengan persentase terendah adalah mengevaluasi $43,52 \%$ dan tertinggi adalah pengaturan diri 59,03\%.
\end{abstract}

Kata kunci : Analisis, Keterampilan Berpikir Kritis

\begin{abstract}
This study aims to determine the percentage level of mastery of critical thinking skills of high school students in District of Sako and District Alang-alang Lebar. This research was conducted with quantitative descriptive methods. Samples were taken by purposive sampling technique. Data collection techniques with non-test and test. Data analysis using Ms. Excel by calculating the percentage level of mastery. The results showed that Sako District was categorized as low with a percentage of $38.99 \%$ and a medium categorized Alang-alang Lebar District with a percentage of $52.99 \%$. The low categorized indicator in Sako District is analyzing $40.09 \%$, evaluating $25.82 \%$, and explaining $34.97 \%$. The highest indicator is self-regulation $53.27 \%$. In Alang-alang District the indicator with the lowest percentage was evaluating $43.52 \%$ and the highest was self-regulation $59.03 \%$.
\end{abstract}

Keywords : Analysis, Critical Thinking Skills 


\section{PENDAHULUAN}

Kualitas pendidikan di Indonesia masih tergolong rendah. Hal tersebut dapat dilihat dari pencapaian Indonesia dalam ajang PISA dan TIMSS pada tahun 2015. Berdasarkan data dari PISA tahun 2015, Indonesia menduduki peringkat 64 dari 72 negara, dengan rata-rata skor pada bidang sains 403 (OECD, 2016:5). Diikuti dengan data dari TIMSS tahun 2015 Indonesia ada pada peringkat 45 dari 48 negara (Puspendik, 2015).

Indonesia saat ini telah menerapkan Kurikulum 2013 sebagai kurikulum nasional. Hal tersebut diharapkan mampu untuk meningkatkan kualitas pendidikan Indonesia di ajang evaluasi seperti PISA dan TIMSS. Berdasarkan Permendikbud nomor 65 tahun 2013 keterampilan dalam K13 didapat dari kegiatan mengamati, menanya, mencoba, menalar, menyaji, dan mencipta. Kegiatan menalar dan menyaji merupakan cerminan dari keterampilan berpikir kritis, artinya keterampilan berpikir kritis menunjang kinerja siswa selama proses pembelajaran.

Proses pembelajaran dalam K13 berorientasi pada pendekatan saintifik yang berhubungan erat dengan sains. Jufri (2017:149) menyatakan bahwa sains bukanlah sekedar kumpulan pengetahuan yang berupa fakta-fakta, konsep-konsep, atau prinsipprinsip tetapi juga merupakan proses mencari dan menemukan. Proses untuk mencari dan menemukan pada pembelajaran sains ditunjang oleh keterampilan berpikir kritis yang dimiliki siswa. Hal ini didukung oleh Mabruroh \& Suhandi (2017:1) yaitu tujuan utama pendidikan sains adalah untuk mempersiapkan siswa memahami konsep dan meningkatkan keterampilan berpikirnya. Salah satu keterampilan berpikir tersebut adalah berpikir kritis.

Keterampilan berpikir kritis, didefinisikan sebagai pemikiran dengan penalaran analitik, penalaran kuantitatif, dan pemecahan masalah (Benjamin, et al., 2013:11). Keterampilan ini memungkinkan seseorang untuk memastikan bahwa dia memiliki alasan yang baik untuk percaya atau melakukan apa yang orang lain coba yakinkan untuk dilakukan atau dipercaya (Bowell \& Kemp, 2005:36).

Keterampilan berpikir kritis dalam bidang akademik dapat membantu siswa mengetahui cara memahami diri sendiri, cara memahami dunia, dan cara bersosialisasi dengan orang lain. Siswa dengan keterampilan berpikir kritisnya bisa menganalisis pemikirannya untuk memastikan dia telah membuat pilihan dan menarik kesimpulan secara tepat. Sejalan dengan pendapat Moore \& Parker (2009:3) yaitu tindakan 
seseorang biasanya bergantung pada pemikiran atau ide yang dimilikinya, seseorang yang cerdas tergantung pada seberapa baik dia mempertimbangkan pemikirannya dan ide-ide yang dimilikinya. Sebaliknya, siswa yang belum mempunyai keterampilan ini, belum bisa memutuskan hal yang harus dipahami, hal yang harus diyakini, keputusan yang perlu diambil, dan cara dalam bertindak. Pada akhirnya, siswa yang belum mempunyai keterampilan berpikir kritis akan percaya begitu saja pada pendapat dan pemahaman orang lain dengan pasif.

Bassham, et al., (2011:7) menyatakan bahwa siswa dalam berpikir kritis mempelajari berbagai hal yang dapat meningkatkan kinerja kelas mereka, termasuk: memahami argumen dan pendapat orang lain, kritis dalam mengevaluasi argumen tersebut, dan mengembangkan serta membela argumen yang didukung dengan baik sesuai dengan pemahamannya. Menurut Facione (2013:9), ada enam indikator yang dapat digunakan untuk mengukur keterampilan berpikir kritis yaitu interpretasi, analisis, evaluasi, inferensi, eksplanasi, dan pengaturan diri. Indikator milik Facione (2013:9) dipilih untuk digunakan dalam penelitian ini karena merupakan indikator terbaru, telah mengalami penyempurnaan dan penataan ulang urutan, dan masing-masing indikator dijelaskan dengan cara yang lebih sederhana menggunakan kata benda dan contoh, sehingga lebih mudah untuk diterapkan dalam lingkungan pendidikan. Rincian deskripsi dari masing-masing indikator ada pada Tabel 1.

Tabel 1. Indikator dan Deskripsi

\begin{tabular}{ccl}
\hline No & Indikator & \multicolumn{1}{c}{ Deskripsi } \\
\hline 1 & Interpretasi & $\begin{array}{l}\text { Kemampuan untuk memahami, menjelaskan, dan memberi } \\
\text { makna data atau informasi. }\end{array}$ \\
\hline 2 & Analisis & $\begin{array}{l}\text { Kemampuan untuk mengidentifikasi hubungan dari informasi- } \\
\text { informasi yang dipergunakan untuk mengekspresikan } \\
\text { pemikiran atau pendapat. }\end{array}$ \\
\hline 3 & Evaluasi & Kemampuan untuk menguji kebenaran. \\
\hline 4 & Inferensi & $\begin{array}{l}\text { Kemampuan untuk mengidentifikasi dan memperoleh unsur- } \\
\text { unsur yang diperlukan untuk membuat suatu kesimpulan yang } \\
\text { masuk akal. }\end{array}$ \\
\hline 5 & Menjelaskan & $\begin{array}{l}\text { Kemampuan untuk menjelaskan atau menyatakan hasil } \\
\text { pemikiran berdasarkan bukti, metodologi, dan konteks. }\end{array}$ \\
\hline 6 & Pengaturan Diri & Kemampuan seseorang untuk mengatur pola berpikirnya. \\
\hline
\end{tabular}


Berdasarkan pengambilan data awal di SMA pada Kecamatan Sako dan SMA pada Kecamatan Alang-alang Lebar, guru di sekolah mengaku telah melakukan penilaian keterampilan berpikir kritis melalui tes essay dan diskusi, namun pada kenyataannya tes yang diberikan oleh guru belum sesuai dengan indikator keterampilan berpikir kritis. Hal tersebut didasarkan pada pernyataan guru bahwa soal-soal yang biasanya digunakan sebagian besar masih pada taraf $\mathrm{C} 1-\mathrm{C} 3$, padahal keterampilan berpikir kritis ada pada taraf $\mathrm{C} 4-\mathrm{C} 5$. Ketidaksesuaian taraf instrumen yang digunakan guru menjadikan keterampilan berpikir kritis siswa belum diukur secara maksimal. Berdasarkan uraian masalah sebelumnya, tujuan penelitian ini untuk mengetahui: 1) persentase tingkat penguasaan keterampilan berpikir kritis siswa SMA di wilayah Kecamatan Sako dan 2) persentase tingkat penguasaan keterampilan berpikir kritis siswa SMA di wilayah Kecamatan Alang-alang Lebar.

\section{METODE}

Penelitian ini menggunakan metode deskriptif kuantitatif yang bertujuan untuk memberikan gambaran mengenai penguasaan keterampilan berpikir kritis siswa. Penelitian ini tidak memberikan perlakuan pada subjek, melainkan hanya memberikan hasil berdasarkan instrumen yang diberikan kepada guru dan siswa.

Sampel diambil dengan teknik purposive sampling. Populasi penelitian adalah siswa SMA di Kecamatan Sako dan Alang-alang Lebar. Sampel penelitian adalah SMA A dan B yang mewakili Kecamatan Sako, SMA C dan D yang mewakili Kecamatan Alang-alang Lebar. Semua sampel merupakan sekolah berakreditasi A dengan nilai diatas 87 .

Instrumen yang digunakan berupa nontes dan tes. Nontes terdiri atas lembar kuesioner dengan 22 pernyataan mengenai penilaian keterampilan berpikir kritis, lembar wawancara terdiri dari 16 pertanyaan terkait penilaian keterampilan berpikir kritis dan 13 pertanyaan terkait hasil analisis data dan keterampilan berpikir kritis, lembar observasi terdiri dari 6 kegiatan yang mewakili masing-masing indikator dengan total pernyataan yaitu 22 item, dan dokumentasi berupa dokumen yang memberikan keterangan dan alat bukti berkaitan dengan proses pengumpulan data. Tes dalam bentuk pilihan ganda beralasan yang dikembangkan oleh Hidayat, Fadillah, dan Harfian (2018). Berdasarkan pendapat dari Cullinane (2011:10), soal pilihan ganda beralasan sangat 
berkontribusi dalam penilaian belajar yang mengarahkan siswa pada tingkat pemikiran lebih tinggi. Siswa diminta untuk menggunakan tingkat berpikir lebih tinggi untuk memberikan alasan dari opsi yang telah dipilih sebelumnya.

Analisis data dilakukan dengan rumus persentase penguasaan untuk melihat penguasaan siswa terhadap masing-masing indikator keterampilan berpikir kritis menggunakan Microsoft Office Excel. Setelah hasil tes terkumpul, hasil tes diberikan skor. Selanjutnya, hasil tes keseluruhan siswa ditotal menjadi skor per sekolah, skor per sekolah kemudian ditotalkan untuk dapat skor per kecamatan. Tingkat penguasaan siswa terhadap indikator yang diujikan dapat dilihat melalui kategori tingkat penguasaan yang diadaptasi dari Azwar (2014:147-149):

Tabel 2. Kategori Tingkat Penguasaan

\begin{tabular}{ccc}
\hline No & Kategori & Persentase Rerata Skor (\%) \\
\hline 1 & Sangat Rendah & $\mathrm{X} \leq 24,95$ \\
2 & Rendah & $24,95<\mathrm{X} \leq 41,65$ \\
3 & Sedang & $41,65<\mathrm{X} \leq 58,35$ \\
4 & Tinggi & $58,35<\mathrm{X} \leq 75,05$ \\
5 & Sangat Tinggi & $75,05<\mathrm{X}$ \\
\hline
\end{tabular}

(Azwar, 2014:147-149)

Rumus persentase penguasaan yang digunakan dalam penelitian ini diadaptasi dari Purwanto (2006:103) sebagai berikut:

$$
\mathrm{NP}=\frac{R}{S M} x 100 \%
$$

$$
\begin{aligned}
& \text { Keterangan: } \\
& \mathrm{NP}=\text { Nilai Persentase per Indikator KBK } \\
& \mathrm{R}=\text { Skor yang didapat pada Indikator KBK } \\
& \mathrm{SM}=\text { Skor maksimum pada Indikator KBK }
\end{aligned}
$$

\section{HASIL DAN PEMBAHASAN}

Hasil analisis keterampilan berpikir kritis siswa SMA di masing-masing kecamatan ada pada Tabel 3.

Tabel 3. Nilai Persentase KBK Siswa SMA per Kecamatan

\begin{tabular}{cccc}
\hline No & Kecamatan & Persentase $(\%)$ & Kategori \\
\hline 1 & Sako & 38,99 & Rendah \\
2 & Alang-alang Lebar & 52,99 & Sedang \\
\hline
\end{tabular}


Hasil analisis data yang disajikan didukung dengan hasil observasi dan wawancara menunjukkan beberapa hal yang menyebabkan rendahnya KBK di Kecamatan Sako. Pertama, sarana dan prasarana di sekolah. Sekolah yang terletak di Kecamatan Sako memiliki sarana dan prasarana kelas yang cukup baik, hanya saja belum dilengkapi dengan LCD projector yang dapat menunjang proses pembelajaran sebagai pendukung terciptanya suansana belajar yang kondusif dan dapat memaksimalkan aktivitas berpikir siswa. Hal selanjutnya yang menyebabkan keterampilan berpikir kritis siswa di Kecamatan Sako rendah adalah kebanyakan siswa kurang percaya diri dan tidak yakin dalam menjawab soal tes yang dibagikan. Ketika soal tes dibagikan, sebagian siswa sudah lebih dulu mengeluh bahwa soal yang dibagikan merupakan soal yang sulit.

Pernyataan sebelumnya didukung oleh Zubaidah (2016:12) bahwa perkembangan teknologi memainkan peran penting dalam pembelajaran dan dapat menciptakan peluang baru yang belum pernah terjadi sebelumnya. Didukung juga oleh Yunita, et al., (2018:36) yaitu siswa memiliki kebiasaan sikap takut atau tidak percaya diri dalam mengerjakan tes terlihat sebelum soal tes dibagikan siswa sudah ingin menyerah tanpa mengetahui tes terlebih dahulu, dan tidak percaya diri dalam jawabannya sendiri sehingga menyebabkan siswa berdiskusi.

Berdasarkan hasil analisis data, observasi, dan wawancara, sekolah di Kecamatan Alang-alang Lebar telah melengkapi sarana dan prasarana kelas dengan adanya LCD projector. Hal tersebut sangat berguna dan membantu meningkatkan proses pembelajaran menjadi lebih menarik bagi siswa. Di Kecamatan Alang-alang Lebar sebagian besar siswa merasa antusias dalam mengerjakan soal-soal tes yang dibagikan.

1. Keterampilan Berpikir Kritis Siswa SMA di Kecamatan Sako

Hasil analisis masing-masing indikator keterampilan berpikir kritis siswa SMA di Kecamatan Sako ada pada Gambar 1. 


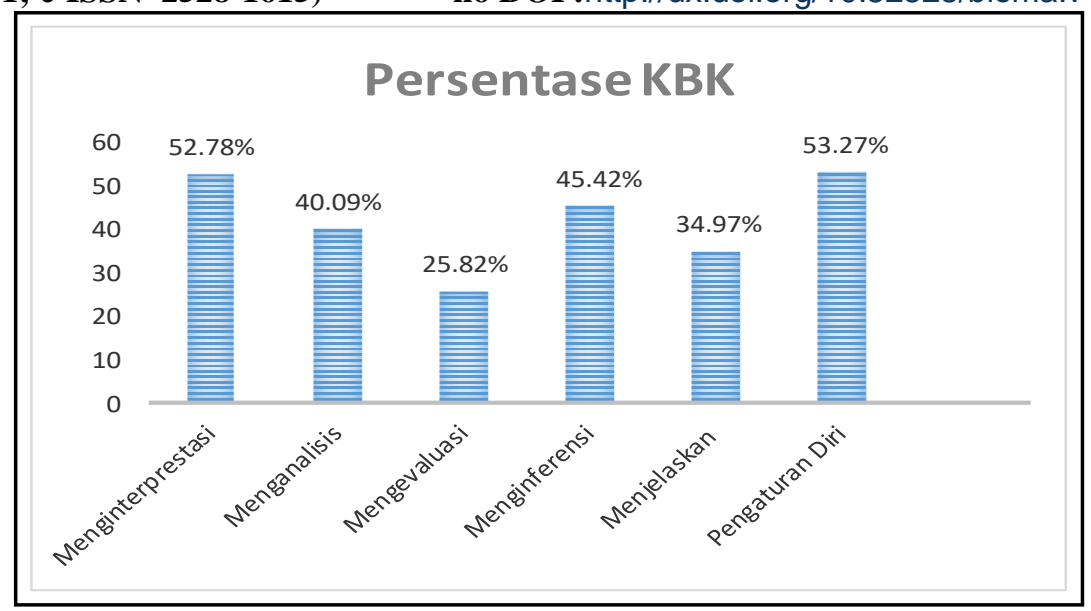

Gambar 1. Persentase Keterampilan Berpikir Kritis Siswa SMA di Kecamatan Sako

Berdasarkan Gambar 1 dapat dilihat bahwa persentase masing-masing indikator bervariasi mulai $25,82 \%$ hingga $53,27 \%$. Indikator pertama yang terkategori rendah adalah menganalisis sebesar 40,09\%. Analisis merupakan kemampuan untuk mengidentifikasi hubungan dari informasi-informasi yang dipergunakan untuk mengekspresikan pemikiran atau pendapat. Sesuai dengan hasil observasi, di Kecamatan Sako kegiatan analisis belum dilaksanakan secara maksimal karena siswa belum dibimbing untuk membuat argumennya terkait permasalahan diskusi, siswa kurang mampu untuk merealisasikan hal-hal yang mereka pelajari ke pemahaman mereka sendiri, akibatnya mereka mengalami kesulitan untuk mengidentifikasi, menganalisis, dan menemukan strategi pemecahan soal. Selanjutnya hasil wawancara, guru menyatakan yang menyebabkan rendahnya kemampuan menganalisis karena siswa belum dibiasakan untuk menganalisis.

Sejalan dengan pendapat Saputri, et al., (2017:133), kemampuan analisis yang rendah disebabkan karena kebanyakan siswa kurang mampu mengidentifikasi atau dengan cepat menolak argumen kontra yang kuat dan relevan. Menurut Haryandi, et al., (2013:265), kemampuan analisis yang rendah dikarenakan sebagian siswa mengalami kesulitan mengidentifikasi variabel yang diketahui, ditanya, dan strategi untuk memecahkan soal yang diberikan. Menurut Suryani, et al., (2016:6), bahwa rendahnya kemampuan siswa dalam menganalis disebabkan oleh kurangnya representasi penyelesaian soal.

Guru di Kecamatan Sako mengungkapkan untuk meningkatkan keterampilan menganalis dengan cara membiasakan mereka untuk menganalisis misalnya, melalui pemberian masalah terkait materi pembelajaran, diberikan kuis, dan melakukan tes 
lisan. Hal tersebut berguna untuk membiasakan mereka memahami hubungan antar konsep dan materi. Suryani, et al., (2016:6) juga mengungkapkan solusi untuk meningkatkan kemampuan menganalisis siswa dengan cara memberikan pemahaman konsep yang terintegrasi, memberikan penjelasan konsep dengan menarik agar siswa mau untuk terus mengolahnya. Arini \& Juliadi (2018:10) juga menyatakan solusi yang sama untuk meningkatkan kemampuan menganalisis yaitu dapat dibantu dengan membiasakan siswa untuk mencari persamaan dengan memberikan pemahaman konsep yang terintegrasi.

Indikator kedua yang terkategori rendah adalah evaluasi sebesar 25,82\%. Evaluasi merupakan indikator yang menunjang siswa untuk mampu menguji kebenaran dan merupakan inti dari keterampilan berpikir kritis. Pendapat tersebut didukung Ruggiero (2012:19) yaitu inti dari keterampilan berpikir kritis adalah evaluasi. Rendahnya kemampuan evaluasi siswa dikarenakan siswa belum dilatih untuk mengecek lagi pertanyaan yang dibuat terhadap kesesuaiannya dengan sebuah permasalahan, dan belum terbiasa untuk menilai sendiri kualitas argumen yang mereka buat dengan berbagai pertimbangan. Sesuai dengan hasil observasi, kegiatan evaluasi belum tercermin dengan baik dalam proses pembelajaran di Kecamatan Sako. Selanjutnya hasil wawancara, rendahnya evaluasi diakibatkan oleh pola pikir siswa untuk mengerjakan soal-soal yang melibatkan keterampilan berpikir tingkat tinggi masih rendah. Kebanyakan siswa belum mampu menjawab soal-soal tipe berpikir tingkat tinggi, soal-soal yang biasa diujikan umumnya masih pada taraf $\mathrm{C} 1-\mathrm{C} 3$, padahal indikator evaluasi ini termasuk taraf C5 dalam taksonomi Bloom, lalu siswa cenderung lebih suka menghafal daripada memahami materi. Hal ini mengakibatkan mereka mudah lupa jika beberapa waktu kemudian materi serupa diujikan kembali.

Pendapat tersebut didukung oleh Nugroho (2018:80) bahwa menghafal telah menjadi kebiasaan sejak lama, siswa dibiasakan dengan menghafal tanpa mengetahui makna. Akibatnya, terbentuk pribadi yang mahir dalam hafalan, tapi lemah dalam penalaran. Menurut Rakhmawati, et al., (2015:983) yaitu rendahnya kemampuan siswa SMA dalam mengevaluasi dapat disebabkan oleh kemampuan siswa mengerjakan soal tipe C4-C5 rendah, hal tersebut dibuktikan ketika mengerjakan soal tes siswa diminta untuk menjelaskan, siswa hanya menyebutkan dan hal tersebut mengindikasikan kemampuan siswa pada umumnya masih dalam taraf C1-C3. Suryani, et al., (2016:7) 
juga mengungkapkan rendahnya kemampuan evaluasi siswa diakibatkan oleh terbatasnya kemampuan mereka dalam menemukan alternatif penyelesaian soal. Menurut Hidayanti, et al., (2016:283), yaitu siswa yang tidak dapat melakukan evaluasi kebenaran dari yang mereka kerjakan, karena siswa tidak terbiasa dengan melihat kembali hasil yang telah mereka dapatkan.

Guru di Kecamatan Sako menyatakan untuk meningkatkan kemampuan mengevaluasi siswa yaitu dengan melatih mereka mengerjakan soal-soal yang melibatkan keterampilan berpikir tingkat tinggi. Hal tersebut berguna untuk membiasakan mereka mengevaluasi pemikirannya. Arini \& Juliadi (2018:10) memberikan solusi yang sama yaitu dengan membiasakan diri untuk mengerjakan soalsoal dengan cara penyelesaian yang bervariasi.

Indikator terakhir yang terkategori rendah adalah menjelaskan sebesar 34,97\%. Pada indikator ini siswa dituntut untuk dapat menjelaskan dan menyatakan hasil pemahaman berdasarkan bukti, masalah-masalah, konsep, dan solusi yang mereka temukan di soal-soal tes ataupun pada materi yang sebelumnya telah diajarkan guru. Hasil observasi menunjukkan guru telah melaksanakan kegiatan yang menunjang indikator menjelaskan, tapi siswa belum dimotivasi untuk berani menyajikan argumennya sendiri terkait permasalahan pada materi pembelajaran. Selanjutnya hasil wawancara, guru menyatakan rendahnya kemampuan menjelaskan yang dimiliki siswa karena sebagian besar dari mereka ragu dengan argumen mereka sendiri dan kurangnya tingkat kepercayaan diri yang mereka miliki. Hal tersebut menyebabkan siswa kurang mampu dalam mempertimbangkan kebenaran dan ketepatan argumen, serta kurang mampu menarik kesimpulan dengan tepat.

Sejalan dengan pendapat dari Arini \& Juliadi (2018:10) bahwa rendahnya kemampuan siswa dalam menjelaskan dikarenakan siswa tidak dapat melakukan penarikan kesimpulan. Pendapat yang sama juga dinyatakan oleh Suryani, et al., (2016:7) yaitu rendahnya kemampuan siswa dalam menjelaskan dikarenakan mereka mengalami kesulitan dalam menarik kesimpulan. Menurut Susilowati, et al., (2017:228), kemampuan siswa rendah dalam menjelaskan adalah kurang mampunya mereka dalam mempertimbangkan bukti, konsep, metodologi, kriteria dan konteks, dan menyajikan penalaran dalam bentuk argumen yang meyakinkan. 
Guru di Kecamatan Sako mengungkapkan solusi untuk meningkatkan kemampuan menjelaskan siswa dengan cara membiasakan mereka berbicara dan berdiskusi. Hal tersebut berguna untuk membiasakan mereka menjelaskan dan meningkatkan rasa percaya diri yang mereka miliki. Menurut Suryani, et al., (2016:7) solusi untuk meningkatkan kemampuan menjelaskan yaitu dengan cara siswa harus dilatih berpikir secara deduktif maupun induktif, adakan diskusi kelas dengan memberikan tugas portofolio, atau melakukan percobaan yang dilakukan dengan metode ilmiah.

Indikator dengan persentase tertinggi adalah pengaturan diri sebesar 53,27\%. Hasil observasi menunjukkan kegiatan yang memfasilitasi pengaturan diri sudah terlaksana dengan baik. Selanjutnya hasil wawancara, guru menyatakan kemampuan pengaturan diri yang baik didapatkan siswa dengan cara mengarahkan dan mengutarakan pemikiran sendiri melalui bimbingan dan arahan dari guru. Siswa juga mampu memberikan solusi ataupun pilihan terbaik untuk dirinya karena pengaturan diri merupakan faktor yang berasal dari diri sendiri.

Sejalan dengan pendapat dari Friskilia S \& Winata (2018:40-41) bahwa siswa dengan kemampuan pengaturan diri yang baik merupakan siswa yang dapat mengatur dan mengelola pikiran, perasaan, keinginan, dan penetapan tindakan yang akan dilakukan. Menurut Sari (2014:29), kemampuan self regulation yang baik dikarenakan siswa dapat menilai dirinya sendiri, mengetahui bagaimana tingkat pemahamannya terhadap suatu materi pembelajaran dan apa yang harus dia lakukan untuk mencapai hasil prestasi yang optimal. Hal yang sama diungkapkan Hidayat (2013:2) bahwa regulasi diri sangat berperan penting dalam mencapai tujuan belajar siswa, khususnya pada pelajaran-pelajaran yang tergolong sulit dan membutuhkan analisis yang tinggi.

2. Keterampilan Berpikir Kritis Siswa SMA di Kecamatan Alang-alang Lebar

Hasil analisis masing-masing indikator keterampilan berpikir kritis siswa SMA di Kecamatan Alang-alang Lebar ada pada Gambar 2.

Berdasarkan Gambar 2, indikator terendah adalah evaluasi sebesar 43,52\% dan tertinggi adalah pengaturan diri sebesar 59,03\%. Seperti halnya di Kecamatan Sako, siswa di Kecamatan Alang-alang Lebar juga memiliki persentase yang cukup rendah pada indikator evaluasi meskipun 43,52\% masih terkategori sedang. 


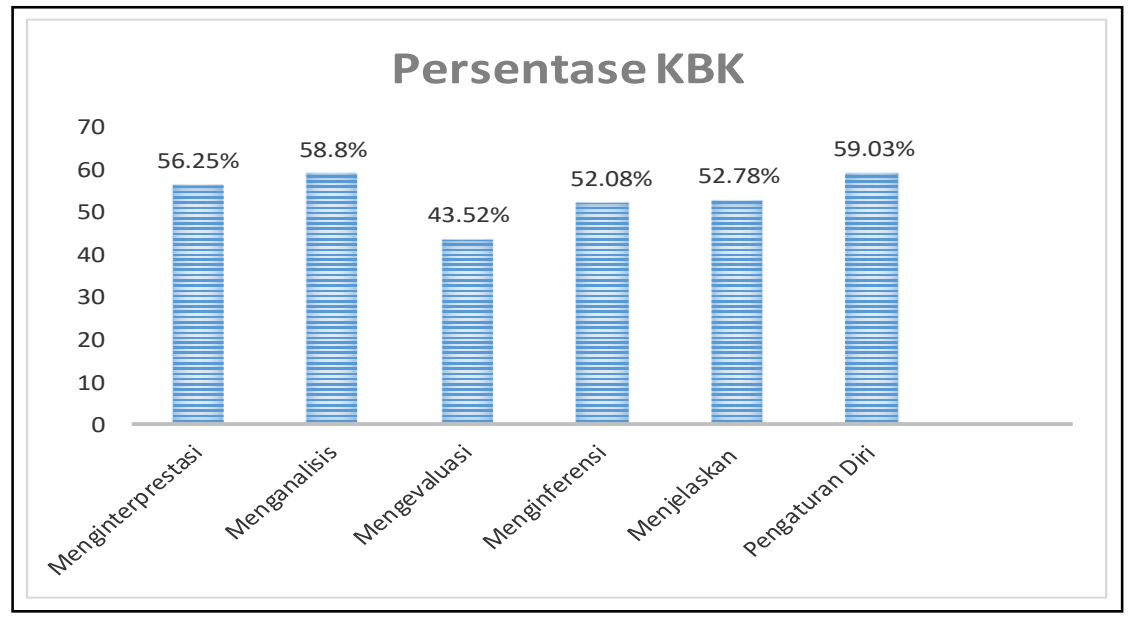

Gambar 2. Persentase Keterampilan Berpikir Kritis Siswa SMA di Kecamatan Alangalang Lebar

Rendahnya kemampuan evaluasi siswa SMA disebabkan karena mereka belum mampu menguji kebenaran. Hasil observasi menunjukkan kegiatan evaluasi belum terlaksana dengan baik, siswa belum dibimbing untuk mengecek dan memilih kembali pertanyaan-pertanyaan yang telah dibuat terhadap kesesuaiannya dengan permasalahan, serta siswa belum dibimbing untuk menilai kualitas argumen yang dibuat. Selanjutnya hasil wawancara, guru menyatakan bahwa kemampuan evaluasi yang rendah dikarenakan siswa kurang memahami materi, lebih sering menghafal hingga mudah lupa pada materi pembelajaran, semangat belajar yang rendah, dan mereka belum terbiasa mengerjakan soal-soal yang melibatkan keterampilan berpikir tingkat tinggi.

Pernyataan tersebut didukung oleh Susilowati, et al., (2017:228) yaitu sebagian besar siswa mengalami kesulitan dalam mengingat materi yang diajarkan di sekolah, siswa juga cenderung lebih terikat dengan metode belajar menghafal dibandingkan memahami yang menjadikan mereka cepat lupa pada materi yang mereka hafalkan tersebut. Pardjono \& Wardaya (2009:268) juga menyatakan bahwa rendahnya kemampuan mengevaluasi dikarenakan siswa tidak terbiasa dengan menyalahkan dan membenarkan hasil pemecahan masalah, sehingga mereka masih canggung dan tidak percaya diri di hadapan guru. Pendapat selanjutnya dari Hayudiyani, et al., (2017:25) yaitu rendahnya kemampuan siswa dalam mengevaluasi diakibatkan oleh mereka tidak dapat memberikan penyelesaian soal dengan baik.

Guru di Kecamatan Alang-alang Lebar memberikan solusi untuk terus meningkatkan kemampuan mengevaluasi siswa dengan cara melaksanakan praktikum, 
mengamati langsung, dan melibatkan siswa dalam rangkaian aktivitas berpikir seperti memecahkan masalah dari sebuah artikel. Nurbaeti, et al., (2015:31) berpendapat bahwa kemampuan evaluasi bisa dilatih melalui latihan, praktek, dan kesabaran dalam kegiatan proses berpikir, sehingga siswa lebih mudah memahami konsep-konsep dan materi.

Persentase paling tinggi $59,03 \%$ adalah pada indikator pengaturan diri. Berdasarkan hasil observasi, kegiatan pengaturan diri telah terlaksana dengan baik. Selanjutnya hasil wawancara, guru menyatakan pengaturan diri yang baik dikarenakan mereka yakin terhadap konsep pembelajaran dan mampu mengaplikasikannya dengan argumen serta solusi dari diri mereka sendiri. Sejalan dengan pendapat Ahmar (2016:20-21), siswa yang cukup memiliki kemampuan regulasi diri meliputi: penetapan tujuan, perencanaan, motivasi (efikasi diri), kontrol atensi, penggunaan strategi belajar atau metode belajar, monitor diri, mencari bantuan, dan evaluasi diri.

Berdasarkan pendapat dari Jakesova \& Kalenda (2015:179), seorang siswa yang telah mencapai tingkat self-regulation yang tinggi merupakan seorang siswa yang sukses. Siswa dengan pengaturan diri yang baik, lebih sering menggunakan strategi untuk mengatur pembelajaran mereka sendiri daripada siswa yang dianggap tidak kompeten. Menurut Mahmood (2017:25), siswa yang memiliki pengaturan diri yang baik tidak lepas dari peranan guru dalam mengatur proses pembelajaran, interaksi yang terjadi di dalam kelas, dan materi ajar yang disampaikan sebagai motivasi eksternal siswa.

\section{KESIMPULAN DAN SARAN}

Dari hasil analisis dan pembahasan, dikemukakan simpulan sebagai berikut: 1) Besar nilai persentase keterampilan berpikir kritis siswa SMA di Kecamatan Sako sebesar 38,99\% dengan kategori rendah. 2) Besar nilai persentase keterampilan berpikir kritis siswa SMA di Kecamatan Alang-alang Lebar sebesar 52,99\% dengan kategori sedang.

Berdasarkan simpulan, maka saran dalam penelitian ini adalah: 1) Untuk guru dan pihak sekolah di Kecamatan Sako dan Alang-alang Lebar diharapkan untuk mengembangkan inovasi-inovasi yang mendukung tercapainya tuntutan penguasaan keterampilan berpikir kritis pada pendidikan abad 21.2) Peneliti selanjutnya diharapkan untuk menggunakan indikator lainnya seperti dari Ennis, dan Paul. Diharapkan juga 
bagi peneliti lain untuk mengukur keterampilan berpikir kritis pada materi lain dalam Biologi.

\section{DAFTAR PUSTAKA}

Ahmar, D. S. (2016). Hubungan antara Regulasi Diri dengan Kemampuan Berpikir Kreatif dalam Kimia Peserta Didik Kelas XI IPA Se-Kabupaten Takalar. Jurnal Sainsmat, 7-23, Vol. V, No. 1, ISSN 2086-6755.

Arini, W., \& Juliadi, F. (2018). Analisis Kemampuan Berpikir Kritis pada Mata Pelajaran Fisika untuk Pokok Bahasan Vektor Siswa Kelas X SMA Negeri 4 Lubuklinggau, Sumatera Selatan. Berkala Fisika Indonesia, 1-11, Volume 10 Nomor 1.

Azwar, S. (2014). Penyusunan Skala Psikologi. Yogyakarta: Pustaka Pelajar.

Bassham, G., Irwin, W., Nardone, H., \& Wallace, J. M. (2011). Critical Thinking: A Student's Introduction (Fourth Edition). New York: McGraw-Hill Companies, Inc.

Benjamin, R., Klein, S., Steedle, J., Zahner, D., Elliot, S., \& Patterson, J. (2013). The Case for Critical-Thinking Skills and Performance Assessment. Collegiate Learning Assessment (pp. 1-26). US: Council for Aid to Education.

Bowell, T., \& Kemp, G. (2005). Critical Thinking: A Concise Guide (Second edition). New York: Routledge.

Cullinane, A. (2011). Two-tier Multiple Choice Questions (MCQs) - How Effective are They: A Pre-service Teachers Perspective. IOSTE - NW Europe, 1-12.

Facione, P. A. (2013). Critical Thinking: What It Is and Why It Counts. Insight Assessment, 1-28.

Friskilia S, O., \& Winata, H. (2018). Regulasi Diri (Pengaturan Diri) sebagai Determinan Hasil Belajar Siswa Sekolah Menengah Kejuruan. Jurnal Pendidikan Manajemen Perkantoran, 37-44, Vol.1, No.2.

Haryandi, S., Zainuddin, \& Suyidno. (2013). Meningkatkan Kemampuan Analisis Sintesis Siswa melalui Penerapan Pengajaran Langsung dengan Metode Problem Solving. Berkala Ilmiah Pendidikan Fisika, 265-270. 
Hayudiyani, M., Arif, M., \& Risnasari, M. (2017). Identifikasi Kemampuan Berpikir Kritis Siswa Kelas X TKJ Ditinjau dari Kemampuan Awal dan Jenis Kelamin Siswa di SMKN 1 Kamal. Jurnal Ilmiah Edutic, 20-27, Vol.4, No.1.

Hidayanti, D., As'ari, A. R., \& Daniel, T. (2016). Analisis Kemampuan Berpikir Kritis Siswa SMP Kelas IX pada Materi Kesebangunan. Konferensi Nasional Penelitian Matematika dan Pembelajarannya (KNPMP I) (pp. 276-285). Surakarta: Universitas Muhammadiyah Surakarta.

Hidayat, A. F. (2013). Hubungan Regulasi Diri dengan Prestasi Belajar Kalkulus Ditinjau dari Aspek Metakognisi, Motivasi, dan Perilaku. Jurnal Elektronik Pendidikan Matematika Tadulako, 1-8, Volume 01, Nomor 01.

Jakesova, J., \& Kalenda, J. (2015). Self-regulated Learning: Critical-realistic Conceptualization. Procedia-Social and Behavioral Sciences, 178-189.

Jufri, H. W. (2017). Belajar dan Pembelajaran Sains Modal Dasar menjadi Guru Profesional. Bandung: Pustaka Reka Cipta.

Mabruroh, F., \& Suhandi, A. (2017). Construction of Critical Thinking Skills Test Instrument Related The Concept on Sound Wave. Journal of Physics, 1-6.

Mahmood, S. (2017). Testing The Effectiveness of a Critical Thinking Skills Intervention for Initial Teacher Education Students in Pakistan. Thesis, University of Southamton.

Moore, B. N., \& Parker, R. (2009). Critical Thinking (19th Editon). New York: The McGraw-Hill Companies, Inc.

Nugroho, R. A. (2018). High Order Thinking Skills (Kemampuan Berpikir Tingkat Tinggi: Konsep, Pembelajaran, Penilaian, dan Soal-soal). Jakarta: Grasindo.

Nurbaeti, Nuryanti, S., \& Puspitasari, I. D. (2015). Hubungan Gaya Belajar dengan Keterampilan Berpikir Kritis dan Kemampuan Kognitif Siswa pada Mata Pelajaran Kimia di Kelas X SMKN 1 Bungku Tengah. e-Jurnal Mitra Sains, 2433, Volume 3, Nomor 2.

OECD. (2016). Result from PISA 2015. Organisation for Economic Co-operation and Development.

Pardjono \& Wardaya. (2009). Peningkatan Kemampuan Analisis, Sintesis, dan Evaluasi melalui Pembelajaran Problem Solving. Cakrawala Pendidikan, 257-269. 
Permendikbud. (2013). Permendikbud Nomor 65 Tahun 2013 tentang Standar Proses.

Retrieved April 17, 2018, from Kementerian Pendidikan dan Kebudayaan: peraturan.go.id/.../kemdikbud-nomor-65-tahun-2013-11e44c5174...

Purwanto, N. (2006). Prinsip-prinsip dan Teknik Evaluasi Pengajaran. Bandung: Remaja Rosdakarya.

Puspendik. (2015). TIMSS infographic. Badan Penelitian dan Pengembangan.

Rakhmawati, T. Y., Rachmadiarti, F., \& Budiono, J. D. (2015). Analisis Keterampilan Berpikir Kritis Siswa SMA Adiwiyata dan SMA Non-Adiwiyata di Tuban. Bioedu, 978-984, Vol.4 No.3, ISSN: 2302-9528.

Ruggiero, V. R. (2012). Beyond Feelings: A Guide to Critical Thinking. New York: The McGraw-Hill.

Saputri, A. C., Sajidan, \& Rinanto, Y. (2017). Identifikasi Keterampilan Berpikir Kritis Siswa dalam Pembelajaran Biologi Menggunakan Window Shopping. Seminar Nasional Pendidikan Sains (pp. 131-135). Surakarta: Universitas Sebelas Maret.

Sari, D. P. (2014). Mengembangkan Kemampuan Self-Regulation: Ranah Kognitif, Motivasi, dan Metakognisi. Delta Pi: Jurnal Matematika dan Pendidikan Matematika, 28-38, Vol. 3, No. 2.

Suryani, I., Yolanda, Y., \& Ariani, T. (2016). Keterampilan Berpikir Kritis Siswa dalam Menyelesaikan Soal Fisika Tentang Impuls dan Momentum. Jurnal Fisika, 1-10.

Susilowati, Sajidan, \& Ramli, M. (2017). Analisis Keterampilan Berpikir Kritis Siswa Madrasah Aliyah Negeri di Kabupaten Magetan. Seminar Nasional Pendidikan Sains (pp. 223-231). Surakarta: Universitas Sebelas Maret.

Yunita, S., Rohiat, S., \& Amir, H. (2018). Analisis Kemampuan Berpikir Kritis Mata Pelajaran Kimia pada Siswa Kelas XI IPA SMAN 1 Kepahiang. Jurnal Pendidikan dan Ilmu Kimia, 33-38.

Zubaidah, S. (2016). Keterampilan Abad ke-21: Keterampilan yang Diajarkan Melalui Pembelajaran. Seminar Nasional Pendidikan (pp. 1-17). Malang: Universitas Negeri Malang. 